\title{
Niepoczytalny sprawca przestępstwa. Rozwój instytucji w prawie angielskim
}

Już w starożytnym Rzymie nie karano sprawców niepoczytalnych. Reskrypt cesarza Hadriana stanowił, iż należy skupiać się nie na rezultacie, lecz woli działającego ${ }^{1}$. Uzasadniano brak karalności, powołując się na niemożność kierowania przez sprawcę swoim postępowaniem. W okresie cesarstwa nie podlegali karze oskarżeni dotknięci szaleństwem (furor), otępieniem (dementia), obłąkaniem (insania), niedołęstwem umysłu (fatuitas) oraz bezmyślni (mentecapti). Uważano, że niepoczytalni zostali wystarczająco ukarani swoim własnym szaleństwem (Fatiinfelicitasexcusat. Satisfuroreipsumpunitur) ${ }^{2}$.

Średniowiecze nie przyniosło rozwoju instytucji niepoczytalności sprawcy czynu karalnego. Przeciwnie, stanowiło regres w porównaniu z dorobkiem starożytnego prawa rzymskiego. Podmiotowa strona czynu nie była brana pod uwagę, skupiano się jedynie na widocznym rezultacie czynu w świecie zewnętrznym. Niepoczytalnych karano tak jak innych sprawców przestępstw. Co więcej, pojawiały się poglądy, że sama niepoczytalność jest efektem opętania lub karą za grzechy. To sprawiało, że ludzie niepoczytalni byli traktowani jak przestępcy, nawet gdy nie dopuścili się żadnego czynu karalnego ${ }^{3}$. Niemniej jednak, w późniejszych wiekach średnich można odnaleźć przejawy światłej myśli, postulującej, aby osoby niemogące kierować swoim postępowaniem ze względu na zaburzenia psychiczne, nie były karane na równi z ludźmi poczytalnymi. Z pewnością przykładem takim może być Zwierciadło Saskie czy Kormcza Kniga, która pojawiła się na Rusi i przewidywała brak karalności osób chorych umysłowo.

Nowożytność to powrót do reguł prawa rzymskiego oraz stopniowe wprowadzenie zasady zwolnienia z karalności niepoczytalnego sprawcy przestępstwa. Takie postulaty wskazywały Statuty Litewskie (XVI w.), Constitutio Cri-

\footnotetext{
${ }^{1}$ S. Ładoś, Pozycja prawna oskarżonego z zaburzeniami psychicznymi, LEX 2013, nr 158180.

${ }^{2}$ S. Waltoś, Owoce zatrutego drzewa, Universitas, Kraków 2010, s. 159.

${ }^{3}$ S. Ładoś, op. cit.
} 
minalis Carolina (XVI w.) czy znany utwór Bartłomieja Groickiego Porządek sądów i spraw miejskich prawa magdeburskiego w Koronie Polskiej, gdzie można znaleźć następujące zdanie: „Od mężobójstwa bywają wymówione te persony: naprzód dzieci, które jeszcze baczenia a rozumu nie mają (...), item ludzie starzy, którzy przez wszytek czas żywota swego zawżdy bez nagany pobożnie żyli” i wreszcie „szaleni, którzy nie wiedzą co czynią (...) i taki, który się porywa ze snu"4.

Jedną z pierwszych znanych regulacji odnoszących się do niepoczytalnego sprawcy przestępstwa było zdanie pochodzące z książki o tytule Eirenarcha, opublikowanej przez Williama Lambarde w 1582 r. ${ }^{5}$ Stwierdzono tam, iż jeśli osoba szalona czy niepoczytalna zabija człowieka, nie jest to przestępstwo, bo sprawca nie może posiadać rozumnej woli ${ }^{6}$.

W 1603 r. w sprawie kryminalnej Lord Coke twierdził, że karanie osoby, która jest pozbawiona rozumu i zrozumienia, nie może być przykładem. Żadne przestępstwo ani morderstwo nie może być popełnione bez przestępczego zamiaru lub celu?

Powyższe próby uregulowania sytuacji prawnej niepoczytalnego sprawcy przestępstwa opierały się przede wszystkim na posiadaniu woli, zamiaru. Przeciwnie niż w większości przypadków znanych historii, regulacje które nastąpiły później stanowiły regres. Przestano kierować uwagę na wolę oskarżonego, starano się początkowo wskazać krąg osób, które należy uznać za niepoczytalne, kolejno ustanawiano liczne testy, które miały pomóc zakwalifikowaniu sprawcy jako niepoczytalnego.

XVII w. w Anglii przyniósł próbę wprowadzenia do słownika prawniczego pojęć związanych z niepoczytalnością. Klasyfikację taką stworzył Lord Coke W swoim dziele Institutes of the Laws of England. W pierwszym tomie traktatów, zwanym Commentary upon Littleton, Lord Coke zaproponował, aby w języku prawniczym używać sformułowania non composmentis. Wyodrębnił cztery kategorie osób, które można zakwalifikować jako non composmentis:

(i) ideota, który od urodzenia poprzez wieczną ułomność jest non composmentis,

(ii) osoba, która poprzez chorobę, smutek lub inny wypadek całkowicie traci pamięć i rozumienie;

(iii) lunatic, który momentami posiada zrozumienie swoich czynów a momentami nie, uznany jest za non composmentis w chwilach gdy zrozumienia takiego nie posiada,

${ }^{4}$ Ibidem.

${ }^{5}$ S.J. Brakel, A.D. Brooks, Law and Psychiatry in the Criminal Justice System, William S. Hein \& Co., Inc, 2001, New York, s.12.

${ }^{6}$,If a mad man or a natural fool, or a lunatic in the time of lunacy (...) do kill a man, this is no felonious act (...) for they cannot be said to have any understanding will".

${ }^{7}$ S.J. Brakel, A.D. Brooks, Law and Psychiatry..., s. 12. 
(iv) osoba, która poprzez własne wadliwe zachowanie powoduje u siebie zanik pamięci i brak rozumienia, jak na przykład nietrzeźwy. Jednak Lord Coke odmawia jakichkolwiek prawnych przywilejów dla ostatniego typu non composmentis ${ }^{8}$.

Oczywiście powyższa klasyfikacja była niedoskonała i niewystarczająca, aby mogła być w pełni użyteczna przy rozpoznawaniu spraw, w których sprawca był niepoczytalny. Nie budzi jednak wątpliwości, iż stanowiła jedną z pierwszych prób klasyfikacji niepoczytalności na potrzeby prawa $\mathrm{w}$ systemie common law. Na jej podstawie starano się uszczegółowić tam, gdzie to możliwe, kategorie non composmentis, tak aby ułatwić klasyfikację osób niepoczytalnych. Niektóre z prób mogą się wydawać obecnie zaskakujące. Jak wskazuje Isaac Ray, twierdzono, że za osobę dotkniętą idiotyzmem można uznać człowieka, który nie potrafi policzyć dwudziestu pensów, stwierdzić, kto jest jego matką lub ojcem lub ile ma lat, nie rozumie również, które działanie powoduje jego zysk, a które szkodę. Jednak już osoba, która nauczyła się, na przykład, czytać, nie kwalifikowała się jako idiota ${ }^{9}$. Już w chwili pisania swojej książki Ray wskazywał, iż regulacje prawne dotyczące niepoczytalności odbiegają od osiągnięć psychiatrii w tym zakresie i nie nadążają za jej rozwojem ${ }^{10}$.

I. Reguła Lorda Hale'a. Przełomową chwilą z punktu widzenia regulacji statusu prawnego niepoczytalnego sprawcy było wprowadzenie reguły Lorda Hale'a. Została ona opublikowana po śmierci autora w książce z 1736 r. $\mathrm{Hi}$ story of the Pleas of the Crown. Powszechnie ówcześnie znane stwierdzenie Lorda Hale'a stało się podstawą do kształtowania się orzecznictwa w zakresie odpowiedzialności karnej niepoczytalnego sprawcy czynu przez kolejne stulecie $^{11}$. Lord Matthew Hale rozróżniał pojęcie niepoczytalności całkowitej i częściowej. Według jego koncepcji jedynie sprawcy czynu całkowicie nie-

${ }^{8}$ Th. Coventry, A readable Edition of Coke upon Littleton, London 1830, sekcja 405, s. 406.

${ }^{9}$ Cyt. za: I. Ray, A Treatise on the medical jurisprudence of insanity, red. Winfred Overholser, A John Harvard Library Book, 1962, Cambridge, Massachusets, s. 14.

${ }^{10}$ Ibidem, s. 5

11 „There is a partial insanity, and a total insanity. The former is either in respect to things, quoad hoc velillud insanire. Some persons that have a competent use of reason in respect of some subjects, are yet under a particular dementia in respect of some particular discourses, subjects, or applications; or else it is partial in respect of degrees; and this is the condition of very many, especially melancholy persons, who for the most part discover their defect in excessive fears and griefs, and yet are not wholly destitute of the use of reason; and this partial insanity seems not to excuse them in the committing of any offense for its matter capital; for, doubtless, most persons that are felons of themselves and others are under a degree of partial insanity when they commit these offenses. It is very difficult to define the invisible line that divides perfect and partial insanity; but it must rest upon circumstances duly to be weighed by judge and jury, lest, on the one side, there be a kind of inhumanity toward the defects of human nature; or, on the other side, too great an indulgence given to great crimes". 
poczytalni mogli być zwolnieni z kary. Niepoczytalność częściową Lord Hale dzielił na dwa rodzaje:

(i) spowodowaną urojeniami i halucynacjami w niektórych momentach, przy prawidłowym funkcjonowaniu umysłu w innych,

(ii) spowodowaną niedostatecznym rozeznaniem swojego postępowania ${ }^{12}$.

II. Reguły Lorda Hale'a w orzecznictwie. W opartym na precedensach systemie common law reguły Lorda Hale'a szybko uległy modyfikacjom w poszczególnych wyrokach. Częstokroć nowe zmiany odnosiły się do wcześniejszych orzeczeń, a niejednokrotnie były z nimi wprost sprzeczne.

Jednym z pierwszych precedensów, którym doprecyzowano i - zdaje się zaostrzono reguły Hale'a, był wyrok sądu w sprawie Edwarda Arnolda (Crazy $\mathrm{Ned}$ ) z 1724 r. Edward Arnold został oskarżony o próbę zabicia Lorda Onslow. Podczas procesu podnoszone były wątpliwości co do jego poczytalności. Został on uznany za winnego przestępstwa przy jednoczesnym stwierdzeniu sądu, iż można zwolnić z kary osobę niepoczytalną jedynie wtedy, gdy niepoczytalność powoduje całkowite pozbawienie danej osoby jakiegokolwiek zrozumienia lub pamięci, która sprawia, że sprawca nie ma świadomości tego, co czyni nie bardziej niż noworodek czy dzika bestia. Wyroki w podobnych sprawach opierały się na teście poczytalności zastosowanym w sprawie Edwarda Arnolda. Sposób badania, czy sprawca jest całkowicie niepoczytalny nazwano wild-beast test (test dzikiej bestii) ${ }^{13}$. Nietrudno zauważyć, że niewielki odsetek sprawców niepoczytalnych test ten przeszedł pozytywnie i w efekcie był zwolniony z odpowiedzialności. Osoby o tak silnych zaburzeniach psychicznych często nie są zdolne do popełniania najcięższych przestępstw. Proces Crazy Neda wskazał kolejny element, który powinien być brany pod uwagę przy orzekaniu, czy sprawca przestępstwa był niepoczytalny. Była to zdolność odróżniania dobra od zła (right from wrong, good from evil). Dopiero brak takiej zdolności mógł doprowadzić do niekaralności sprawcy ${ }^{14}$.

Założenia testu i w ogólności reguła Hale'a odmawiały zwolnienia z karalności sprawcom przestępstw, których poczytalność była ograniczona. W związku z tym w prawie angielskim nastąpił dysonans. Inaczej traktowano osoby niepoczytalne częściowo na podstawie prawa karnego, a inaczej na podstawie prawa cywilnego. Na podstawie prawa karnego byli traktowani tak jak zwykli sprawcy przestępstw. Natomiast na podstawie prawa cywilnego

${ }^{12}$ S. Waltoś, Owoce zatrutego drzewa, s. 161.

13 „It is not every kind of frantic humor, or something unaccountable in a man's actions, that points him out to be such a madman as is exempted from punishment: it must be a man that is totally deprived of his understanding and memory, and doth not know what he is doing, no more than an infant, than a brute or a wild beast; such a one is never the object of punishment".

${ }^{14}$ I. Ray, A Treatise on the medical jurisprudence of insanity, red. Winfred Overholser, A John Harvard Library Book, 1962, Cambridge, Massachusets, s. 31. 
przyjmowano ich ograniczoną zdolność do dokonywania czynności wywołujących skutek prawny ${ }^{15}$. Taki stan był powszechnie uznawany, co nie oznacza, że nie budził krytyki. Z punktu widzenia dzisiejszej nauki prawa wypowiedź prokuratora generalnego (attorney-general) sir Vicary'ego Gibbsa na procesie Bellingham w 1812 r., twierdzącego, iż człowiek może mieć niewystarczający intelekt, co uniemożliwi mu dokonywanie czynności życia codziennego czy rozporządzania swoją własnością, niemniej jednak osoba taka nie jest zwolniona z odpowiedzialności karnej za swoje czyny $^{16}$, budzi zdziwienie. Również Lord Erskine w swej słynnej obronie w sprawie Hadfield, o której mowa będzie poniżej, przyznał obowiązywanie odrębnych zasad dla traktowania czynów osoby niepoczytalnej w prawie cywilnym i prawie karnym. Podobna rozbieżność była krytykowana na kontynencie. Nie budzi zdziwienia twierdzenie francuskiego psychiatry Étienne-Jean Georgeta, iż doktryna Lorda Hale’a zdaje się przedkładać własność nad życie, gdyż brak jest względów dla człowieka, który popełnił przestępstwo w stanie niepoczytalności. Natomiast gdyby w tym stanie dokonał czynności cywilnoprawnej, mogłaby ona zostać anulowana ze względu na stan jego umysłu ${ }^{17}$.

Co widoczne, prawne regulacje odnoszące się do działań osób niepoczytalnych były niedoskonałe i wymagały dalszego precyzowania i rozwoju.

Kolejnym ważnym procesem $\mathrm{w}$ kształtowaniu sytuacji niepoczytalnego sprawcy przestępstwa był wspomniany wyżej proces Hadfielda i błyskotliwa obrona prowadzona przez Lorda Erskina. Sprawa dotyczyła próby zastrzelenia króla. Linią obrony była oczywiście niepoczytalność sprawcy. Prokurator próbował obalić tę teorię, powołując się na „test dzikiej bestii”. W odpowiedzi Lord Erskine stwierdził, że gdyby brać dosłownie sformułowania dotyczące całkowitego braku pamięci i zrozumienia, to tego typu niepoczytalność nigdy nie istniała. Wskazał on również, iż we wszystkich sprawach, które były rozpoznawane w Westminster Hall, niepoczytalni sprawcy przestępstw nie byli całkowicie pozbawieni pamięci ani zrozumienia tego co czynili. Ich zachowanie wynikało często z zaburzeń w postrzeganiu i rozumieniu świata, źródło ich myśli było zwodnicze. Oskarżony Hadfield został uniewinniony, mimo że zdawał sobie sprawę z natury swojego czynu, zaplanował go i spodziewał się kary za jego dokonanie. Niemniej jednak nie budziło wątpliwości, że był niepoczytalny. Sąd orzekający w tej sprawie odstąpił od klasyfikowania niepoczytalności na podstawie „testu dzikiej bestii” czy też „testu odróżniania dobra od zła" i zawyrokował na podstawie zdrowego rozsądku.

${ }^{15}$ H. Maudsley, Law and Insanity, „Popular Science Monthly” Vol. 5, May 1874.

16 „A man may be endangered in his mind - his intellects may be insufficient for enabling him to conduct the common affairs of life, such as disposing of his property (...) and if he be so, the administration of the country will take his affairs into their management (...) but, at the same time such a man is not discharged from his responsibility for criminal acts".

${ }^{17}$ I. Ray, A Treatise on the medical jurisprudence, s. 24. 
Bezpośrednim następstwem procesu Hadfielda była ustawa parlamentu brytyjskiego o niepoczytalnych sprawcach przestępstw (Criminal Lunatics $A c t$ ), uchwalona jeszcze w 1800 r. Nakazywała ona umieszczanie niepoczytalnych w specjalnych zakładach zamkniętych bez wskazywania maksymalnego czasu pobytu. Przed tym aktem prawnym nie było ustaw, które regulowałyby sytuację prawną osób uniewinnionych w wyniku stwierdzenia niepoczytalności. Zazwyczaj były one wypuszczane na wolność, mimo że nie budziło wątpliwości, iż częstokroć stanowiły zagrożenie. Istniały odrębne procedury, które w pewnym stopniu umożliwiały zatrzymanie osób, które według sądu mogły być niebezpieczne. Jednak Criminal Lunatics Act był pierwszą ustawą regulującą ten problem bezpośrednio.

Niestety, 12 lat po wyroku w sprawie Hadfielda miał miejsce proces oskarżonego Bellinghama, który został skazany za morderstwo, mimo że jego niepoczytalność nie budziła wątpliwości (również dla sądu orzekającego). Sędzia Mansfield, orzekający w sprawie, stwierdził, powołując się na obowiązujące prawo i autorytet mędrców angielskich, że osoba, która może być niezdolna do prowadzenia własnych spraw, może być odpowiedzialna za przestępstwo, jeśli posiada umysł zdolny do odróżniania dobra od zła ${ }^{18}$. Po chwilowym zwycięstwie zdrowego rozsądku nad wszelakimi testami sąd znowu oparł swój wyrok, kwalifikując sprawcę na podstawie „testu odróżniania dobra od zła”. Doprowadziło to do absurdalnej sytuacji: mimo że niepoczytalność oskarżonego była niewątpliwa, został on skazany. Tłumaczono jednocześnie, iż owszem, w prawie cywilnym korzystałby z ochrony prawa ze względu na stan swojego umysłu, jednakże w prawie karnym ochrona taka mu nie przysługuje. Sama sprawa Bellinghama ukazuje, jak niedoskonały był użyty przez sąd test. Mimo że kryterium odróżniania dobra od zła było już podnoszone w sprawie Arnolda, to dopiero tutaj nadano mu tak silne znaczenie i skazano człowieka niepoczytalnego. Istotne jest, że badano, czy sprawca posiada taką umiejętność w ogóle, a nie tylko w odniesieniu do konkretnego czynu, za który był sądzony. Warto zwrócić uwagę, że Hadfield został uniewinniony, mimo iż zdawał on sobie sprawę z charakteru swojego czynu i odróżniał dobro od zła, jednak jego niepoczytalność powodowała, że nie mógł on swobodnie kierować własnym postępowaniem. Sąd nie wziął tego pod uwagę w sprawie Bellinghama.

Jednak prawo się zmieniało, sądy odeszły od „testu dzikiej bestii”, skupiając się jednocześnie na generalnej umiejętności odróżniania przez sprawcę dobra od zła. Nie zapominajmy również, że jednocześnie obowiązywał precedens z procesu Hadfielda, gdzie doszło do uniewinnienia ze względu na to, że przestępstwo zostało spowodowano chorobliwymi złudzeniami oskarżonego.

18 „Upon the authority of the first sages in the country, and upon the authority of the established law in all times, which has never been questioned, that although a man might be incapable of conducting his own affairs, he may still be answerable for his criminal acts, if he possess a mind capable of distinguishing right from wrong". 
W 1840 r. miało miejsce zdarzenie, które doprowadziło do kolejnego procesu, istotnie kształtującego linię orzeczniczą w sprawie niepoczytalnych sprawców przestępstw. W tym roku Edward Oxford wystrzelił z dwóch pistoletów do ciężarnej wówczas królowej Wiktorii, nie czyniąc jej jednak żadnej krzywdy. Ze względu na osobę ofiary proces stał się bardzo głośny. Po sprawie Bellinghama, która była znaczącym regresem w porównaniu do sprawy Hadfielda, Edward Oxford został uniewinniony ze względu na stwierdzoną niepoczytalność. Biorąc pod uwagę medialność sprawy oraz fakt, iż oskarżenie próbowało dyskredytować próby udowodnienia niepoczytalności oskarżonego, dowód przeprowadzony z zeznań lekarzy psychiatrów, opis nienaturalnego zachowania oskarżonego w trakcie przestępstwa i po nim, wykazanie, że zarówno ojciec jak i dziadek oskarżonego cierpieli na zaburzenia psychiczne oraz zeznania matki oskarżonego wskazujące na silną traumę przeżytą w dzieciństwie, spowodowały, iż ława przysięgłych go uniewinniła.

Jak wyżej wskazano, rozbieżność pomiędzy wyrokami w sprawie Hadfielda, Bellinghama i Oxforda, a zwłaszcza uzasadnienia wyroków Hadfielda i Bellinghama, sprawiały że w pierwszej połowie w XIX w. obowiązywały dwie niespójne ze sobą reguły ${ }^{19}$.

III. Sprawa M'Naughtona. Istniała więc potrzeba ustalenia jednolitej reguły, którą sądy mogłyby stosować przy orzekaniu o niepoczytalności sprawców przestępstw. Nastąpiło to $\mathrm{w}$ wyniku jednego z najważniejszych precedensowych procesów w Anglii, w procesie M'Naughtona z 1843 r. Oskarżonym był Daniel M’Naughton, który 20 stycznia 1843 r. postrzelił Edwarda Drummonda, prywatnego sekretarza ówczesnego premiera Roberta Peela. Drummond w wyniku ran postrzałowych zmarł kilka dni później. Proces M'Naughtona był niezwykle ciekawym wydarzeniem, śledzonym i szeroko komentowanym przez prasę angielską. Jak ustalono w trakcie procesu na podstawie zeznań świadków, celem ataku M’Naughtona miał być premier Robert Peel. Edward Drummond został postrzelony w wyniku pomyłki sprawcy. Linia obrony opierała się na niepoczytalności sprawcy, jako że sam fakt dokonania czynu przez oskarżonego nie budził wątpliwości. Został on zatrzymany na miejscu przestępstwa przez funkcjonariusza policji, gdy próbował oddać drugi strzał.

Oskarżenie przewidziało, jaka będzie linia obrony, dlatego w przemówieniu oskarżyciel sir William Webb Follet przypomniał ławie przysięgłych:

„aby wyłączyć odpowiedzialność, nie wystarczy by [oskarżony] pozostawał pod wpływem częściowej niepoczytalności (...), jeśli jego intelekt był na takim poziomie, że miał on możliwość odróżnienia dobra od zła, jeśli wiedział jakie mogą

${ }^{19} \mathrm{H}$. Maudsley, Law and Insanity. 
być następstwa jego przestępstwa, które mimo to popełnił świadomie, a z tą świadomością popełnił je umyślnie"20.

W wypowiedzi tej widać nawiązanie do opisywanej powyżej umiejętności rozróżnienia dobra od zła. Chociaż oskarżyciel nie wskazywał już na „test dzikiej bestii", który od sprawy Bellinghama nie był używany, podkreślał, że aby uniewinnić sprawcę czynu, jego niepoczytalność musi być całkowita. Jest to podstawa reguły Lorda Hale’a, która wskazywała, iż poczytalność częściowa w żadnym wypadku nie powoduje uniewinnienia sprawcy. Oskarżenie przedstawiło świadków oraz zgromadziło dowody, z których wynikało, że M’Naughton był poczytalny, miał umiejętność prowadzenia własnych spraw, dobrze radził sobie w pracy. Przygotowywał się również do popełnienia przestępstwa, gromadząc broń i amunicję oraz wyczekując ofiary w miejscu przestępstwa.

Obrona, prowadzona przez Aleksandra Cockburna, przedstawiła dowody wskazujące, iż oskarżony miał silne złudzenia, że jest on bezustannie śledzony przez torysów, co uniemożliwiało mu normalne życie. Obrona powołała na świadków również lekarzy, którzy mieli wypowiedzieć się o poczytalności M’Naughtona. Należy podkreślić, iż w procesie angielskim nie było wówczas instytucji znanej na kontynencie jako eksperci czy biegli. Wprowadzenie dowodu z zeznań lekarzy wymagało od obrony dokładnego uzasadnienia i stanowiło novum w procesie. Zeznania te, obok zeznań świadków obrony, okazały się kluczowym dowodem w sprawie.

Zanim jednak Aleksander Cockburn przedstawił dowody obrony, wiedząc, że oskarżenie próbowało wykazać, iż oskarżony jest poczytalny lub przynajmniej nie całkowicie niepoczytalny, zaprezentował ławie przysięgłych i sądowi przemówienie, które przeszło do historii.

Cockburn musiał uporać się z doktryną Hale'a, przedstawiając jej ostrożną krytykę, wskazując na powoływane tu wielokrotnie dzieło amerykańskiego psychiatry Isaaca Raya, jak również na obronę Erskina w procesie Hadfielda. Zwrócił również uwagę ławy przysięgłych, iż ich obowiązkiem jest zdecydowanie, czy oskarżony winny jest umyślnego przestępstwa. Jednocześnie podkreślił, że umyślne (willful) działanie należy rozumieć

„nie w tym sensie, że człowiek podnosi rękę przeciw drugiemu, nie w sensie ciemnego instynktu wiodącego do popełnienia irracjonalnego czynu, gdyż brutalne stwory, dzikie zwierzęta w tym właśnie sensie mają wolę, ale trzeba to słowo rozumieć jako chęć w związku z ludzkim działaniem, sens mu nadaje konieczne moralne uczucie, które powoduje i kieruje wolą poprzez rozum, wywołując działanie" $" 21$.

\footnotetext{
${ }^{20}$ S. Waltoś, Owoce zatrutego drzewa, s. 172.

${ }^{21}$ Ibidem, s. 189-204.
} 
Przesłuchanie lekarza psychiatry, doktora Monro, pozwoliło zmierzyć się Cockburnowi z ostatnim testem, a mianowicie umiejętnością odróżniania dobra od zła, która była tak silnie eksponowana od procesu Bellignhama. Obrońca zadał pytanie: „Czy może istnieć niepoczytalność przy równoczesnym moralnym spostrzeganiu tego, co jest złe, a co jest dobre?’ Odpowiedź doktora Monro nie pozostawiała żadnego miejsca na interpretacje: „Tak, jest to bardzo powszechne"22.

M'Naughton został uniewinniony, jednak z uwagi na obowiązujący wówczas Criminal Lunatics Act z 1800 r., o którym mowa powyżej, został umieszczony w zamkniętym zakładzie, gdzie spędził resztę życia.

Jak wskazuje Stanisław Waltoś, dzisiejsi psychiatrzy nie mają wątpliwości, iż M’Naughton był schizofrenikiem paranoidalnym, miał urojenia i halucynacje, omamy słuchowe i wzrokowe. Uważa się, że schizofrenia paranoidalna jest nieuleczalna ${ }^{23}$.

Uniewinnienie M’Naughtona wywołało falę krytyki, również królowa Wiktoria w liście do premiera Peela (który, przypomnijmy, był rzeczywistym celem działań M’Naughtona) wskazała, iż decydowanie o niepoczytalności spoczywa wyłącznie w rękach sędziów, zaproponowała uregulowanie tej kwestii w taki sposób, aby sędziowie przy wyrokowaniu w podobnych sprawach byli związani pewnymi regułami ${ }^{24}$. Niepokój królowej Wiktorii był zrozumiały, biorąc pod uwagę, że w najgłośniejszych sprawach, w których doszło do uniewinnienia niepoczytalnego sprawcy czynu, celem ataku byli przedstawiciele władzy lub członkowie rodziny królewskiej (sprawa Hadfielda, Oxforda i M'Naughtona).

W bezpośrednim następstwie procesu powstały reguły M'Naughtona, które wywarły ogromny wpływ na pozycję niepoczytalnych sprawców przestępstw. Były one efektem działań Izby Lordów, która zaprosiła kilkunastu sędziów najwyższych instancji i zadała im 5 pytań. Odpowiedzi na nie stały się podstawą reguły M'Naughtona, która obowiązuje do dzisiaj, uzupełniona przez Homicide Act z 1957 r., o którym mowa będzie poniżej. W skrócie, zgodnie z formułą M’Naughtona:

1. Sprawca odpowiada karnie, jeśli w czasie popełniania przestępstwa wiedział, że działa niezgodnie z prawem, bez względu na wpływ urojenia.

2. Przysięgli powinni być pouczani, iż zakłada się, że każdy człowiek jest poczytalny, chyba że zostanie przeprowadzony dowód odwrotny. Aby zaakceptować twierdzenie o niepoczytalności, obrona musi wykazać, że: (i) sprawca w czasie przestępstwa pozostawał pod wpływem takiej choroby umysłowej, że nie znał istoty i jakości czynu albo (ii) znał istotę i jakoś czynu, ale

\footnotetext{
22 Ibidem, s. 207.

${ }^{23}$ Ibidem, s. 211-212.

24 Ibidem, s. 215.
} 
nie wiedział, iż to co czyni jest złe ${ }^{25}$. Po tym pouczeniu wystarczyło zapytać przysięgłych, czy sprawca miał w dostatecznym stopniu świadomość, że to, co uczynił, było złe. W efekcie właśnie temu testowi byli poddawani sprawcy w celu stwierdzenia, czy byli niepoczytalni w chwili czynu. Musieli albo nie znać istoty i jakości czyni, albo znając je, nie wiedzieć, że to co robią jest złe.

3. Kolejne pytanie było de facto oceną sprawy M’Naughtona. Sędziowie stwierdzili, że sprawca pozostający w chwili czynu pod wpływem urojenia powinien ponosić taką odpowiedzialność, jak gdyby fakty, w stosunku do których zachodziły urojenia, były realne. Na przykład, sprawca, którego urojenie polega na tym, że ktoś chce go zabić, pozbawia życia tę osobę, będzie zwolniony z odpowiedzialności. Jednakże, gdyby zabił tę osobę, a jego urojenie polegałoby na tym, że osoba ta chce mu wyrządzić krzywdę, ale nie zabić, będzie odpowiadał karnie. Biorąc pod uwagę tę regułę, M’Naughton powinien był być skazany.

4. Sędziowie orzekli, iż lekarz może być świadkiem, nawet jeśli nie leczył oskarżonego, ale może zeznawać jedynie na tematy związane ściśle z medycyną. Nie można pytać go, czy sprawca był niepoczytalny, gdyż byłoby to pytanie o ocenę faktów, co jest rolą przysięgłych ${ }^{26}$.

IV. Krytyka reguł M'Naughtona. Formuła M'Naughtona opiera się więc w dużym stopniu na umiejętności rozróżniania dobra od zła. Mimo iż Cockburn podczas przesłuchań psychiatrów w sprawie M'Naughtona wykazał, że jest to kryterium niepoprawne oraz że często zdarza się, że niepoczytalni rozróżniają dobro od zła, mimo wszystko popełniając jednak przestępstwo. Powyższe reguły były więc pewnym krokiem wstecz w porównaniu do wyroków w sprawie Hadfielda czy Oxforda. Niemniej jednak, zgodnie z regułami M’Naughtona należało badać powyższą umiejętność w czasie popełnienia czynu, a nie w ogólności, jak postulowano po procesie Bellinghama, co z oczywistych względów było bardziej racjonalnym rozwiązaniem.

Ponadto krytyce była poddawana reguła wskazana w punkcie 3. powyżej. Wskazywano, że oczekuje się od niepoczytalnego, aby w swej chorobie był na tyle rozumny, iżby potrafił ocenić, czy osoba nieposiadająca urojeń w takiej samej sytuacji i w poczuciu podobnego zagrożenia byłaby usprawiedliwiona w danym typie działania. Jak wskazał w swym artykule Henry Maudsley ${ }^{27}$, angielski psychiatra: reguła ta nakładała na niepoczytalnego sprawcę obowiązek bycia racjonalnym $\mathrm{w}$ jego irracjonalności, poczytalnym $\mathrm{w}$ jego niepoczytalności ${ }^{28}$.

${ }^{25}$ „At the time of committing the act, the accused was laboring under such a defect of reason, from disease of the mind, as not to know the nature and quality of the act he was doing or, if he did know it, that he did not know what he was doing was wrong".

${ }^{26}$ Ibidem, s. 218-219.

${ }^{27} \mathrm{H}$. Maudsley, Law and Insanity.

${ }^{28},(\ldots)$ he is, in fact, bound by to be reasonable in his unreason, sane in his insanity”. 
Formule M’Naughtona można było postawić jeszcze jeden istotny zarzut. Otóż nie przewidywała ona częstych sytuacji, gdy sprawca działał pod wpływem nieodpieralnego impulsu (irresistible impulse), to jest gdy zdawał sobie sprawę z czynu, który chce popełnić, ale jego zaburzenia psychiczne powodowały iż nie mógł on kierować swoim działaniem. Obrońcy próbowali uzupełnić ten brak, powołując się w procesach na działanie pod wpływem impulsu. Jednak próby te były zazwyczaj przez sądy dyskredytowane. W sprawie R. v. Ronald True w 1922 r. podnoszono podczas procesu, że sprawca - Ronald True, oskarżony o morderstwo prostytutki, działał pod wpływem nieodpieralnego impulsu. Sędzia pouczył ławę przysięgłych, iż może uznać oskarżonego za niepoczytalnego, gdy uzna, że nie był on w stanie kontrolować swojego postępowania. Taka możliwość nie była przewidziana w regułach M’Naughtona. Argumentowano w ten sposób, iż u osoby, której siła woli została zniszczona przez chorobę umysłową, mogło dojść do zaburzenia zdolności odróżniania dobra od zła ${ }^{29}$. Wyjaśnienie to stanowiło już bezpośrednie odniesienie do reguł M’Naughtona. Jednak oskarżony został uznany za winnego i skazany. Uznano, że nieodparty impuls, jeśli w ogóle istnieje, jest defektem woli a nie rozumu i w związku z tym nie stanowi podstaw do uznania sprawcy za niepoczytalnego. W 1923 r. została ustanowiona Komisja do spraw Niepoczytalności i Zbrodni (Commission on Insanity and Crime), która obradowała pod przewodnictwem znanego prawnika Lorda Justice Atkina. W raporcie przedstawionym przez komisję wskazano, iż sprawca powinien być zwolniony z odpowiedzialności, gdy popełnił przestępstwo pod wpływem impulsu, któremu ze względu na swoją chorobę psychiczną nie mógł się oprzeć. Rekomendacja ta została odrzucona przez Izbę Lordów $\mathrm{w}$ toku dyskusji po opublikowaniu raportu komisji ${ }^{30}$.

Dwa lata później w sprawie Kopsch z 1925 r., w której obrona również podnosiła, że sprawca działał pod wpływem niekontrolowanego impulsu, sąd stwierdził, iż jest to fantastyczna teoria, jednak gdyby miała zostać wprowadzona do prawa karnego byłaby jedynie wywrotowa ${ }^{31}$. W Anglii negatywne skutki braku takiego testu zostały częściowo zmienione przez Homicide Act z $1957 \mathrm{r}^{32}$

Poza tym reguły M'Naughtona nie odnoszą się do żadnych konkretnych zaburzeń psychicznych, mówią jedynie o chorobie umysłu. $Z$ tego powodu obejmują szereg zaburzeń, które obecnie nie są wystarczające, aby uznać kogoś za niepoczytalnego. Reguły opierają się nie na określeniu, co powoduje niepra-

${ }^{29}$ A. Felthous and H. Sass, International Handbook on Psychopathic Disorders and the Law, Vol. II, Laws and Policies, 2007 West Sussex, s. 247.

${ }^{30}$ Law Commission, Reforming the Law, Insanity and Automatism, Supplementary Material to the Scoping Paper, s.173, http://lawcommission.justice.gov.uk/docs/insanity_scoping_supplementary.pdf.

${ }^{31}$ C.K.G. Pillay, Drawing Line on Irresistible Impulse, „New Straits Times”, 3 lutego 1994.

${ }^{32}$ M. Jefferson, Criminal Law, wyd. 7, Essex, England 2007, s. 335-338. 
widłowości, a jedynie na ich opisie, to jest skutku stanów chorobowych, a więc niemożności poznania istoty swego czynu lub zrozumienia, że to, co czyni sprawca, jest złe. Jednakże, jak wskazano powyżej, błędem fatalnym w skutkach (na przykład sprawa Roberta True) było nieuwzględnienie w tych skutkach niemożności kierowania własnym postępowaniem w taki sposób, jak to ujmujemy dzisiaj, a co podówczas nazywano nieodpartym impulsem. Jak wiemy, obecne regulacje niepoczytalności opierają się częstokroć na metodzie biologiczno-psychologicznej. Oznacza to, iż wskazuje się dość szeroko zakreślony krąg zaburzeń psychicznych oraz wynikające $\mathrm{z}$ nich ograniczenia w zachowaniu osoby nimi dotkniętej (np. art. 31 polskiego kodeksu karnego z 1997 r: „Nie popełnia przestępstwa, kto, z powodu choroby psychicznej, upośledzenia umysłowego lub innego zakłócenia czynności psychicznych, nie mógł w czasie czynu rozpoznać jego znaczenia lub pokierować swoim postępowaniem”).

Kolejnym zarzutem jest powtarzający się już wyjątek od reguły Lorda Hale'a dotyczący braku pośredniego stanu pomiędzy całkowitą niepoczytalnością a poczytalnością. Nadal nie było reguł łagodzących odpowiedzialność osób częściowo niepoczytalnych. Ten brak, jak również częściowo brak uwzględnienia nieodpieralnego impulsu (czy bardziej poprawnie z punktu widzenia psychiatrii - niemożności kierowania własnym postępowaniem), zostały częściowo usunięte przez Homicide Act z 1957 r., który był pierwszą większą regulacją wpływającą na reguły M'Naughtona od czasów ich uchwalenia.

W czasie, gdy w Anglii zaczęto używać reguł M'Naughtona, które z punktu widzenia dzisiejszej nauki prawa były rozwiązaniem niedoskonałym, w porównaniu z obowiązującymi w ówczesnej Europie kontynentalnej kodyfikacjami, były one bardzo rozwojowe i precyzyjne.

We Francji, zgodnie kodeksem karnym z 1810 r., nie było zbrodni ani występku, jeśli sprawca znajdował się w stanie obłąkania umysłu. Landrecht Pruski z 1794 r. stanowił, iż nieletni i upośledzeni na umyśle mogą być przedmiotem dalszego postępowania prowadzącego do zastosowania środków ochrony, nie mogą jednak być karani stosownie do surowości ustawy. Kodeks karny Bawarii zawierał zdecydowanie lepsze rozwiązania niż obydwa powyższe, stanowiąc że odpowiedzialności karnej nie podlegają szaleńcy, obłąkani lub osoby, które pod wpływem melancholii lub innej ciężkiej choroby umysłowej, utraciły rozsądek i w tym stanie popełniły przestępstwo; idioci, którzy całkowicie nie mają możliwości oceny następstw swego czynu lub świadomości, że czyn jest karalny; osoby upośledzone otępieniem starczym, skutkiem czego nie posiadają władz umysłowych. Jednak również w tym przypadku brak mowy o zwolnieniu z odpowiedzialności w razie niemożności kierowania swoim postępowaniem. $Z$ tego względu krytyka reguł M'Naughtona staje się $\mathrm{w}$ tym zakresie aktualna również $\mathrm{w}$ tym przypadku ${ }^{33}$.

\footnotetext{
${ }^{33}$ S. Waltoś, Owoce zatrutego drzewa, s. 222.
} 
V. Homicide Act z 1957 r. Przyczynkiem do uchwalenia Homicide Act w 1957 r. były konkluzje wysnute przez Komisję Królewską ds. Kary Śmierci (Royal Commission on Capital Punishment), która obradowała od 1949 do 1953 r. Komisja wytknęła wszystkie wady Reguł M’Naughtona, wskazując, że opierają się one na zupełnie błędnym rozumieniu niepoczytalności, gdyż odnoszą je jedynie do zdolności poznawczych i intelektualnych, podczas gdy niepoczytalność dotyka całej osobowości, w tym również emocji oraz woli. Jak wskazano wyżej, reguły M’Naughtona odnosiły się do możliwości rozpoznania swojego czynu przez sprawcę lub zrozumienia tego czy to, co czyni, jest złe. Nie było tu miejsca na badanie, czy sprawca mógł swobodnie zadecydować o swoim działaniu (impuls, niemożność kierowania swoim postępowaniem). Komisja rekomendowała, aby rozszerzyć reguły M’Naughtona o właśnie takie przypadki, jak również wprowadzić możliwość uniewinnienia ze względu na ograniczoną poczytalnośćc ${ }^{34}$. Rekomendacje komisji również w tym przypadku nie zostały w pełni wprowadzone w praktykę. Reguły M'Naughtona pozostały niezmienione. Wprowadzono jednak do Homicide Act w 1957 r. instytucję ,zmniejszonej odpowiedzialności” (diminished responsibility).

Instytucja powyższa wprowadzała zasadę iż osoba, która popełnia zabójstwo z powodu nieprawidłowości (abnormality) umysłu, która w znacznym stopniu ograniczała jego umysłową odpowiedzialność (mental responsibility) za jego czyny lub zaniechania, nie powinna być skazana za zabójstwo.

Różnica pomiędzy obroną z powołaniem się na pełną niepoczytalność (plea of insanity) oraz na zmniejszoną poczytalność (dimished responsibility) opiera się na tym, że udowodnienie pełnej niepoczytalności całkowicie zwalnia sprawcę z odpowiedzialności (complete defence), w świetle prawa nie jest on odpowiedzialny za to, co zrobił. Ograniczona poczytalność powoduje, iż sprawca zostaje skazany za morderstwo popełnione w związku z ograniczeniem poczytalności, co nie pociąga za sobą obowiązkowego orzeczenia kary śmierci i jest przesłanką do złagodzenia kary ${ }^{35}$. Należy jednak podkreślić, że możliwość obrony opartej na poczytalności ograniczonej dotyczyła jedynie sprawców zabójstw.

Od czasu Homicide Act z 1957 r. nie zmieniono w istotny sposób formuły M’Naughtona, która razem ze wspomnianą ustawą oraz obszernym orzecznictwem nadal stanowi test, na podstawie którego określa się niepoczytalność

${ }^{34}$ Law Commission, Reforming the Law, Insanity and Automatism, Supplementary Material to the Scoping Paper, s. 174-176, http://lawcommission.justice.gov.uk/docs/insanity_scoping_supplementary.pdf oraz J. Higgins, The origins of the Homicide Act, Regional Forensic Psychiatry Service, Liverpool, ,Journal of medical ethics”, 1986, 12, s. 8-12.

${ }^{35}$ Law Commission, Reforming the Law, Insanity and Automatism, Supplementary Material to the Scoping Paper, s. 19, http://lawcommission.justice.gov.uk/docs/insanity_scoping_supplementary.pdf. 
sprawcy przestępstwa. Jednak krytyka podnoszona już bezpośrednio po ich wprowadzeniu jest coraz wyraźniejsza. Istnieje potrzeba wprowadzenia reguł odzwierciedlających osiągnięcia myśli prawniczej oraz rozwój psychiatrii, co pozwala przypuszczać, iż w niedługim czasie nastąpi gruntowna reforma reguł. 